\title{
Pengaruh Kompetensi Kerja Dan Lingkungan Kerja Terhadap Peningkatan Kinerja Aparatur Sipil Negara Di Kantor Kecamatan Luyo Kabupaten Polewali Mandar
}

\author{
Rivai Makduani \\ Institut Agama Islam DDI Polewali Mandar \\ Jl. Gatot Soebroto Kelurahan Madatte Kecamatan Polewali Kab. Polewali Mandar
}

\begin{abstract}
ABSTRAK
Penelitian ini bertujuan untuk mengetahui dan menganalisis pengaruh kompetensi kerja dan lingkungan kerja baik secara parsial maupun secara simultan terhadap peningkatan kinerja Aparatur Sipil Negara di Kantor Kecamatan Luyo Kabupaten Polewali Mandar.

Berdasarkan tujuan penelitian yang ingin dicapai maka penelitian ini merupakan penelitian explanatory research dan merupakan penelitian survey (survey research) dengan pendekatan kuantitatif. Populasi dalam penelitian ini adalah seluruh Aparatur Sipil Negara yang ada di Kantor Kecamatan Luyo Kabupaten Polewali Mandar yang berjumlah 18 orang. Pengambilan sampel dilakukan dengan teknik total sampling sehingga sampel sebagai sumber data sebanyak 18 responden. Metode pengumpulan data yang digunakan adalah metode observasi, pengisian angket oleh responden, dan dokumentasi. Teknik analisis data yang digunakan adalah teknik analisis statistik deskriptif dan teknik analisis statistik inferensial (uji normalitas data dan analisis regresi linier berganda).

Hasil penelitian menunjukkan bahwa: (1) Kompetensi kerja berpengaruh positif dan signifikan terhadap peningkatan kinerja Aparatur Sipil Negara di Kantor Kecamatan Luyo Kabupaten Polewali Mandar dengan tingkat pengaruh sebesar 19,89\%. (2) Lingkungan kerja berpengaruh positif dan signifikan terhadap peningkatan kinerja Aparatur Sipil Negara di Kantor Kecamatan Luyo Kabupaten Polewali Mandar dengan tingkat pengaruh sebesar 17,89\%. (3) Secara simultan dan langsung, kompetensi kerja dan lingkungan kerja berpengaruh positif dan signifikan terhadap peningkatan kinerja Aparatur Sipil Negara di Kantor Kecamatan Luyo Kabupaten Polewali Mandar dengan tingkat pengaruh sebesar $25,2 \%$. Sedangkan sisanya sebesar 74,8\% dipengaruhi faktor-faktor lain yang tidak dapat dijelaskan dalam penelitian ini.
\end{abstract}

Kata Kunci: Kompetensi Kerja, Lingkungan Kerja, Peningkatan Kinerja

\section{PENDAhULUAN}

\section{A. Latar Belakang}

Pelaksanaan tugas dan pekerjaan merupakan suatu kewajiban bagi para anggota dalam suatu organisasi, baik dalam organisasi pemerintah maupun non pemerintah. Dalam pelaksanaan tugas dan kewajiban tersebut terdapat suatu tujuan yang sama, yakni mengharapkan suatu hasil yang baik serta memuaskan sesuai dengan apa yang telah ditentukan sebelumnya. Untuk mendapatkan suatu hasil kerja yang baik sesuai dengan tujuan, maka setiap organisasi mempunyai suatu aturan yang 
dituangkan dalam bentuk kebijakan. Kebijakan ini dibuat dengan maksud agar tiap komponen organisasi melaksanakan tugas sesuai dengan tujuan yang ditetapkan. ${ }^{1}$

Dengan diberlakukannya Undang-Undang 22 tahun 1999 yang kemudian direvisi menjadi Undang-Undang 32 tahun 2004 tentang Pemerintahan Daerah, yang selanjutnya direvisi menjadi Undang-Undang 23 tahun 2014 tentang Pemerintahan Daerah, bangsa Indonesia mengalami perubahan yang sangat mendasar dari berbagai bidang termasuk di dalam penyelenggaraan Pemerintahan. Undang-Undang 23 tahun 2014 memberikan kewenangan yang sangat luas kepada Pemerintah Daerah di dalam menyelenggarakan pemerintahannya. Sesuai dengan hal tersebut, Pemerintah Daerah mengemban tugas yang sangat besar dari seluruh aspek kinerja birokrasi pemerintahan pada umumnya, sehingga perlu adanya kontribusi yang nyata dari Pemerintah Daerah.

Undang-Undang 23 tahun 2014 Tentang Pemerintahan Daerah yang sarat dengan isu strategi berupa kelembagaan, sumber daya manusia berupa aparatur pelaksana, jaringan kerja serta lingkungan kondusif yang terus berubah merupakan sebuah tantangan bagi Pemerintah Daerah untuk meningkatkan kinerja dalam mencapai tujuan pelayanan kepada masyarakat. Undang-undang ini diidentifikasi diantaranya adalah menempatkan pemerintahan Kecamatan dan Kelurahan sebagai perangkat daerah otonom, yaitu daerah Kabupaten dan daerah Kota. Dengan kata lain, pemerintahan Kecamatan menempati posisi sebagai kepanjangan tangan pemerintah daerah otonom (desentralisasi) dan bukan sebagai aparat dekonsentrasi.

Sebagai konsekwensi dari perubahan ini maka pemerintahan Kecamatan tidak lagi menjalankan urusan-urusan dekonsentrasi yang merupakan urusan-urusan pemerintah pusat yang ada di daerah. Camat tidak lagi menjadi kepala wilayah yang merupakan wakil pemerintah pusat yang menjadi penguasa tunggal di bidang pemerintahan dalam wilayahnya, yang memimpin pemerintahan, mengkoordinasikan pembangunan dan membina kehidupan masyarakat di segala bidang. Urusanurusan yang dilaksanakan oleh pemerintahan Kecamatan adalah urusan-urusan yang merupakan pelimpahan sebagian kewenangan pemerintahan dari bupati/walikota.

Berdasarkan uraian di atas, jelas bahwa pemerintah Kecamatan merupakan ujung tombak bagi pelaksanaan penyelenggaran pemerintahan di daerah dan keberhasilannya sangat ditentukan oleh dukungan seluruh jajaran di wilayahnya, terutama dukungan kinerja para pegawainya atau aparat Kecamatan. Untuk memperoleh dukungan seluruh jajaran secara efektif dan efisien, perlu diterapkan teknik atau prisip kepemimpinan yang tepat dari seorang Camat. Sehubungan beratnya tugas dan kewajiban Camat tesebut, maka dalam menjalankan roda pemerintahan, melaksanakan pembangunan dan memberikan pelayanan kepada masyarakat, Camat harus memiliki kemampuan memanajemen agar seluruh jajarannya dapat bekerjasama mewujudkan tujuan organisasi Kecamatan. Khususnya dalam meningkakan kinerja pegawai atau aparatur Kecamatan untuk memberikan pelayanan yang optimal kepada masyarakat.

Kinerja suatu birokrasi publik merupakan suatu isu yang sangat aktual yang terjadi pada masa sekarang ini. Masyarakat masih memandang kinerja dari birokrasi publik pada saat ini belum bisa memberikan rasa kepuasan yang tinggi, sehingga menyebabkan penyelenggaraan pemerintahan menjadi sorotan yang tajam, terutama dalam aspek transparansi, akuntabilitas, efisiensi dan

${ }^{1}$ Girsang, Manajemen Sumber Daya Manusia dan Organisasi (Yogyakarta: Graha Ilmu, 2011), h. 52. 
efektifitas. Hal tersebut disebabkan masyarakat mulai kritis dalam memonitor dan mengevaluasi manfaat serta nilai yang diperoleh atas pelayanan dari instansi pemerintah.

Di sisi lain, pengukuran keberhasilan maupun kegagalan instansi pemerintah dalam menjalankan tugas pokok dan fungsinya sulit dilakukan secara obyektif, yang dapat menginformasikan tingkat keberhasilan secara obyektif dan terukur dari pelaksanaan programprogram di suatu instansi pemerintah.

Informasi mengenai kinerja aparatur dan faktor-faktor yang ikut berpengaruh terhadap kinerja aparatur sangat penting untuk diketahui, sehingga pengukuran kinerja aparat hendaknya dapat diterjemahkan sebagai suatu kegiatan evaluasi untuk menilai atau melihat keberhasilan dan kegagalan pelaksanaan tugas dan fungsi yang dibebankan kepadanya.

Pada dasarnya kunci keberhasilan suatu organisasi yang bergerak dalam bidang jasa terletak pada pelayanan yang diberikan kepada masyarakat (pengguna jasa). Pelayanan dan kepuasan masyarakat sebagai pengguna jasa merupakan suatu aspek vital dalam rangka mempertahankan eksistensi suatu organisasi. Meskipun demikian, untuk mewujudkan kepuasan secara menyeluruh tidaklah mudah, apalagi masyarakat sekarang lebih terdidik dan telah memahami haknya. Masyarakat akan selalu memperhatikan semua haknya dan secara semaksimal akan menggunakannya untuk mendapatkan kebutuhan. Menurut Soekarwo, diskriminasi pelayanan sering kali muncul karena presepsi mengenai hak dan kewajiban antara penyedia layanan dan pengguna layanan belum mencapai titik temu. Misalnya, hak bagi setiap pengguna layanan untuk mendapatkan perlakuan yang wajar dan ramah dari penyedia layanan. Hal tersebut jarang sekali dipenuhi bahkan terjadi hal sebaliknya, yaitu justru pengguna layanan yang harus bersikap ramah terhadap penyedia layanan agar urusannya menjadi cepat dan lancar. ${ }^{2}$

Tuntutan masyarakat untuk mendapatkan pelayanan publik yang berkualitas, prosedur jelas, waktu ringkas dan biaya pantas terus meningkat dari waktu ke waktu. Tuntutan ini berkembang seiring dengan berkembangnya kesadaran bahwa warga Negara memiliki hak untuk dilayani, dan kewajiban pemerintah untuk memberikan pelayanan.

Seiring dengan pelaksanaan otonomi daerah, peluang untuk mengembangkan pelayanan publik yang tepat sasaran perlu mendapatkan perhatian yang serius. Pelayanan pada masyarakat merupakan tuntutan yang tidak bisa diabaikan, masyarakat merupakan bagian terpenting dari keberadaan kelangsungan suatu organisasi Negara.

Profesi pegawai negeri sipil yang merupakan ujung tombak pemberian pelayanan di pemerintahan, hendaknya sangat diperhatikan dan dikelola secara professional, sehingga mampu memberikan kontribusi yang positif bagi masyarakat dan kemajuan lembaga pemerintah melalui peningkatan kinerja. ${ }^{3}$

Untuk dapat menjalankan tugas dan fungsi sekaligus dapat memuaskan pelanggannya (masyarakat), dipandang perlu untuk melakukan beberapa bentuk usaha. Salah satu bentuk usaha yang dimaksud adalah peningkatan kompetensi aparatur melalui kegiatan pendidikan, pelatihan dan

\footnotetext{
${ }^{2}$ Yusuf Hayat, "Pengaruh Kualitas Layanan Terhadap Kepuasan Konsumen, Citra Perusahaan, dan Loyalitas Konsumen Pada Perusahaan Jasa (Studi Pada Jasa Penerbangan di Sulawesi Selatan)" Tesis, (Malang: Program Pascasarjana Unibraw, 2014), h. 3-4.

${ }^{3}$ Wahyuni, Pelayanan Publik di Era Globalisasi (Semarang: Unnes Press, 2014), h. 28.
} 
pengembangan pada segenap tingkatan. Diharapkan dengan dilakukannya pendidikan, pelatihan dan pengembangan aparatur maka kualitas aparatur meningkat yang kemudian dapat berimbas pada meningkatnya kinerja aparatur dalam memberikan pelayanan guna memuaskan masyarakat sebagai pelanggannya.

Menurut Sumarsono bahwa kinerja individu merupakan pondasi kinerja organisasi. Faktor penting dalam keberhasilan suatu organisasi adalah adanya pegawai yang mampu dan terampil serta mempunyai semangat kerja yang tinggi, sehingga dapat diharapkan suatu hasil kerja yang memuaskan. ${ }^{4}$ Di lain pihak, Wijaya dan Suhaji mengungkapkan bahwa pada kenyataannya tidak semua pegawai mempunyai kemampuan dan ketrampilan serta semangat kerja sesuai dengan harapan organisasi. Seorang pegawai yang mempunyai kemampuan sesuai dengan harapan organisasi, kadang-kadang tidak mempunyai semangat kerja tinggi sehingga kinerjanya tidak sesuai dengan yang diharapkan. ${ }^{5}$

Menurut Boediono bahwa salah satu faktor yang mempengaruhi kinerja pegawai adalah kompetensi kerja yang dimiliki pagawai. Usaha untuk dapat meningkatkan kinerja pegawai diperlukan kompetensi yang memadai. ${ }^{6}$ Kompetensi mempunyai peranan yang amat penting, karena pada umumnya kompetensi menyangkut kemampuan dasar seseorang untuk melakukan suatu pekerjaan. Untuk mencapai hasil kerja yang maksimal dan memuaskan diperlukan kompetensi yang dimiliki oleh seorang pegawai dalam melaksanakan tugas kerjanya agar kinerja pegawai dapat meningkat.

Menurut Sarworini, kemampuan atau kompetensi adalah sifat yang di bawa sejak lahir/dipelajari yang memungkinkan seseorang menyelesaikan tugasnya. Kompetensi menunjukkan potensi orang untuk melaksanakan tugas/pekerjaan. Kompetensi pegawai dalam melaksanakan tugasnya merupakan perwujudan dari pengetahuan dan ketrampilan yang dimiliki. ${ }^{7}$

Robbins menjelaskan bahwa kompetensi terdiri dari kompetensi intelektual dan kompetensi fisik. Kompetensi intelektual adalah kemampuan yang diperlukan untuk menjalankan kegiatan mental, sedangkan kompetensi fisik adalah kemampuan yang diperlukan untuk melakukan tugastugas yang menuntut stamina, kecekatan, kekuatan dan keterampilan. ${ }^{8}$

Kompetensi dapat digunakan untuk memprediksi kinerja, yaitu siapa yang berkinerja baik dan kurang baik tergantung pada kompetensi yang dimilikinya, diukur dari kriteria atau standar yang digunakan. ${ }^{9}$ Peningkatan kompetensi kerja pegawai sangat diperlukan dalam mendukung kemampuan kerja sekaligus menentukan tingkat kinerja yang dihasilkan pegawai. Semakin tinggi kompetensi kerja aparatur/pegawai maka kinerja aparatur/pegawai akan semakin optimal dan pelayanan yang diberikan pada masyarakat akan semakin berkualitas sehingga masyarakat sebagai pelanggannya akan semakin terpuaskan.

\footnotetext{
${ }^{4}$ Sumarsono, Evaluasi Kinerja Organisasi (Jakarta: Bumi Aksara. 2012), h. 74.

${ }^{5}$ Wijaya dan Suhaji, Produktivitas dan Kinerja Organisasi (Jakarta: Bumi Aksara, 2013), h. 41.

${ }^{6}$ B. Boediono, Pelayanan Prima Perpajakan (Jakarta: Rineka Cipta, 2013), h. 37.

${ }^{7}$ Sarworini, Produktivitas Kerja Dalam Organisasi (Yogyakarta: Graha Ilmu, 2013), h.67.

${ }^{8}$ Stephen P. Robbins, Prinsip-Prinsip Perilaku Organisasi (Jakarta: Erlangga, 2011), h.192.

${ }^{9}$ Ratminto dan Atik Septiwinarsih, Manajemen Pelayanan (Yogyakarta: Pustaka Pelajar, 2012), h. 41.
} 
Selain kompetensi kerja, salah satu faktor lain yang juga dapat mempengaruhi kinerja aparatur/pegawai adalah lingkungan kerja. Lingkungan kerja aparatur/pegawai juga sangat penting dalam mempengaruhi kinerja aparatur/pegawai tersebut. Menurut Sedarmayanti, lingkungan kerja adalah keseluruhan alat perkakas dan bahan yang dihadapi, lingkungan sekitarnya dimana seseorang bekerja, metode kerjanya, serta pengaturan kerjanya baik sebagai perseorangan maupun sebagai kelompok. Lingkungan kerja yang baik dapat mendukung pelaksanaan kinerja sehingga dapat meningkatkan kinerja pegawai. Semakin baik lingkungan kerjanya, maka semakin meningkat pula kinerja para pegawai. Maka dari itu, suatu organisasi seharusnya menyediakan lingkungan kerja yang baik, seperti lingkungan fisik maupun non fisik. ${ }^{10}$

Kecamatan Luyo merupakan suatu Instansi Pemerintah Daerah Kabupaten Polewali Mandar, dimana aparatur/pegawai di lingkungan Kecamatan Luyo dalam aktifitas bekerjanya selalu berupaya untuk mencapai kinerja yang tinggi guna mencapai tujuan organisasi pemerintahan Kecamatan Luyo. Namun, untuk mencapai kinerja yang tinggi, senantiasa diperlukan aparatur/pegawai yang mempunyai kompetensi yang mampu melaksanakan tugas dan tanggung jawabnya secara profesional dan didukung oleh lingkungan kerja yang kondusif, sehingga kinerja yang dihasilkan dapat optimal sesuai tujuan organisasi.

Berdasarakan latar belakang masalah yang telah diuraikan, maka penting dilakukan penelitian tentang pengaruh kompetensi kerja dan lingkungan kerja terhadap kinerja aparatur/pegawai di di lingkungan Kecamatan Luyo Kabupaten Polewali Mandar.

\section{B. Rumusan Masalah}

Berdasarkan latar belakang masalah yang telah diuraikan, maka masalah pokok dalam penelitian ini dapat dirumuskan sebagai berikut:

1. Bagaimana pengaruh kompetensi kerja terhadap peningkatan kinerja Aparatur Sipil Negara di Kantor Kecamatan Luyo Kabupaten Polewali Mandar?

2. Bagaimana pengaruh lingkungan kerja terhadap peningkatan kinerja Aparatur Sipil Negara di Kantor Kecamatan Luyo Kabupaten Polewali Mandar?

3. Bagaimana pengaruh kompetensi kerja dan lingkungan kerja secara simultan terhadap peningkatan kinerja Aparatur Sipil Negara di Kantor Kecamatan Luyo Kabupaten Polewali Mandar?

\section{Hipotesis Penelitian}

Adapun hipotesis yang dapat dirumuskan berdasarkan rumusan masalah dalam penelitian ini adalah:

1. Kompetensi kerja berpengaruh positf dan signifikan terhadap peningkatan kinerja Aparatur Sipil Negara di Kantor Kecamatan Luyo Kabupaten Polewali Mandar.

2. Lingkungan kerja berpengaruh positf dan signifikan terhadap peningkatan kinerja Aparatur Sipil Negara di Kantor Kecamatan Luyo Kabupaten Polewali Mandar.

\footnotetext{
${ }^{10}$ Sedarmayanti, Tata Kerja dan Produktivitas Kerja (Bandung: Mandar Maju, 2011), h.31.
} 
3. Kompetensi kerja dan lingkungan kerja secara simultan berpengaruh positf dan signifikan terhadap peningkatan kinerja Aparatur Sipil Negara di Kantor Kecamatan Luyo Kabupaten Polewali Mandar.

\section{Tujuan Penelitian}

Sesuai dengan rumusan masalah yang telah ditetapkan, maka tujuan yang ingin dicapai dalam penelitian ini adalah sebagai berikut:

1. Untuk mengetahui dan menganalisis pengaruh kompetensi kerja terhadap peningkatan kinerja Aparatur Sipil Negara di Kantor Kecamatan Luyo Kabupaten Polewali Mandar.

2. Untuk mengetahui dan menganalisis pengaruh lingkungan kerja terhadap peningkatan kinerja Aparatur Sipil Negara di Kantor Kecamatan Luyo Kabupaten Polewali Mandar.

3. Untuk mengetahui dan menganalisis pengaruh kompetensi kerja dan lingkungan kerja secara simultan terhadap peningkatan kinerja Aparatur Sipil Negara di Kantor Kecamatan Luyo Kabupaten Polewali Mandar.

\section{E. Manfaat Penelitian}

1. Secara Teoritis

Untuk menambah referensi di bidang karya ilmiah dan bahan bacaan yang berguna dalam meningkatkan pengetahuan tentang kompetensi kerja dan kinerja Aparatur Sipil Negara serta pentingnya sumber daya manusia dalam pengembangan dan pencapaian tujuan organisasi.

2. Secara Praktis

a. Sebagai bahan informasi, masukan, dan sumbangan pemikiran kepada Camat Kecamatan Luyo pada khususnya dalam rangka menyusun satu kebijakan untuk meningkatkan kompetensi kerja Aparatur Sipil Negara menjadi lebih baik dan meningkatkan kinerja Aparatur Sipil Negara menjadi lebih optimal.

b. Dapat menjadi sumber data atau informasi terhadap masyarakat, khususnya masyarakat Kecamatan Luyo mengenai kompetensi kerja dan kinerja Aparatur Sipil Negara di Kantor Kecamatan Luyo Kabupaten Polewali Mandar.

\section{METODE PENELITIAN}

Berdasarkan tujuan penelitian yang ingin dicapai maka penelitian ini merupakan penelitian explanatory research, yaitu jenis penelitian yang bertujuan untuk mengetahui hubungan pengaruh antara dua buah variabel atau lebih. Melalui explanatory research akan dapat dibangun suatu teori yang dapat berfungsi untuk menjelaskan, meramalkan, dan mengontrol suatu gejala atau fenomena. ${ }^{11}$ Penelitian ini dirancang dengan menggunakan variabel kompetensi kerja sebagai variabel bebas satu $\left(\mathrm{X}_{1}\right)$ dan variabel lingkungan kerja sebagai variabel bebas dua $\left(\mathrm{X}_{2}\right)$ dan variabel peningkatan kinerja Aparatur Sipil Negara sebagai variabel terikat (Y).

Populasi dalam penelitian ini adalah seluruh Aparatur Sipil Negara yang ada di Kantor Kecamatan Luyo Kabupaten Polewali Mandar yang berjumlah 18 orang. Karena jumlah populasi

\footnotetext{
${ }^{11}$ Syofian P. Siregar, Statistik Deskriptif Untuk Penelitian (Jakarta: Raja Grafindo Persada, 2010), h. 108.
} 
dalam penelitian ini hanya 18 orang, maka pengambilan sampel dilakukan dengan teknik total sampling, yaitu pengambilan sampel secara penuh, artinya seluruh populasi dijadikan responden penelitian, sehingga penelitian ini menjadi penelitian populasi.

Jenis data yang digunakan berdasarkan sumbernya meliputi data primer dan data sekunder. Data primer dalam penelitian ini merupakan data yang diperoleh secara langsung dari responden melalui pengisian kuesioner atau angket oleh responden. Data sekunder yang dikumpulkan dalam penelitian ini antara lain data jumlah aparatur/pegawai, data hasil kerja aparatur, data absensi aparatur, dan data populasi/sampel di Kantor Kecamatan Luyo Kabupaten Polewali Mandar serta data-data lain yang mendukung. Sumber data sekunder antara lain monografi, dokumen-dokumen maupun bentukbentuk lain yang dapat memberikan informasi terkait penelitian ini dan juga buku-buku literatur, arsip-arsip, perundang-undangan, dan dokumen resmi yang telah disusun oleh para ahli yang berhubungan dengan masalah yang diteliti.

Metode pengumpulan data yang digunakan dalam penelitian ini adalah metode observasi, pengisian angket oleh responden, dan dokumentasi. Observasi dilakukan dengan cara mengamati secara langsung tehadap subyek maupun obyek penelitian untuk mendapatkan data yang relevan. Pada penelitian ini, pengamatan dilakukan di Kantor Luyo Kabupaten Polewali Mandar. Penggunaan angket/kuesioner dalam penelitian ini bertujuan untuk mencari data tentang kompetensi kerja, kondisi lingkungan kerja dan kinerja Aparatur Sipil Negara di Kantor Kecamatan Luyo Kabupaten Polewali Mandar. Dokumentasi yang dilakukan dalam penelitian ini bertujuan untuk untuk menunjang datadata yang telah diperoleh melalui observasi dan pengisian kuesioner.

Teknik analisis data yang digunakan dalam penelitian ini adalah teknik analisis statistik deskriptif dan teknik analisis statistik inferensial (uji normalitas data, analisis regresi linier berganda, dan uji hipotesis). Analisis statistik deskriptif digunakan untuk mendeskripsikan data yang ada pada penelitian ini yang terdiri dari variabel kompetensi kerja $(\mathrm{X})$ dan variabel peningkatan kinerja aparatur (Y). Uji normalitas suatu data sampel merupakan prasyarat untuk analisis selanjutnya, seperti analisis perbandingan, hubungan antara dua varibel atau lebih dan analisis pengaruh satu varibel bebas atau lebih terhadap varibel terikat. Uji normalitas data dalam penelitian ini menggunakan bantuan komputer melalui paket program SPSS for windows 21. Untuk mengukur pengaruh variabel bebas yaitu kompetensi kerja $\left(\mathrm{X}_{1}\right)$ dan lingkungan kerja $\left(\mathrm{X}_{2}\right)$ terhadap variabel terikat berupa peningkatan kinerja Aparatur Sipil Negara (Y) di Kantor Kecamatan Luyo digunakan analisis regresi linear berganda. Analisis regresi linear berganda dalam penelitian ini dilakukan dengan menggunakan paket program SPSS for windows 21.

Analisis regresi pada dasarnya adalah studi mengenai ketergantungan variabel dependen dengan satu atau lebih variabel independen, dengan tujuan untuk mengestimasi dan atau memprediksi rata-rata populasi atau nilai rata-rata variabel dependen berdasarkan nilai variabel yang diketahui. ${ }^{12}$ Uji hipotesis yang digunakan adalah Uji-t dan Uji Koefisien Determinasi $\left(\mathrm{R}^{2}\right)$. Uji-t digunakan untuk menguji apakah setiap variabel independent yaitu kompetensi kerja $\left(\mathrm{X}_{1}\right)$ dan lingkungan kerja $\left(\mathrm{X}_{2}\right)$ secara parsial mempunyai pengaruh yang positif dan signifikan terhadap variabel dependent yaitu

\footnotetext{
${ }^{12}$ Imam Ghozali, Aplikasi Analisis Multivariate dengan Program SPSS (Semarang: B-P UNDIP, 2013), h. 185.
} 
peningkatan kinerja Aparatur Sipil Negara (Y). Uji Koefisien Determinasi $\left(\mathrm{R}^{2}\right)$ digunakan untuk mengetahui besarnya pengaruh variabel bebas terhadap variabel terikat.

\section{HASIL PENELITIAN DAN PEMBAHASAN}

\section{A. Hasil Penelitian}

Analisis deskriptif digunakan untuk mengetahui hasil tanggapan responden terhadap variabel-variabel yang digunakan melalui item kuesioner yang diajukan. Distribusi frekuensi hasil jawaban responden merupakan tingkat kecenderungan persepsi terhadap variabel-variabel penelitian, yaitu kompetensi kerja, lingkungan kerja dan kinerja Aparatur Sipil Negara di Kantor Kecamatan Luyo Kabupaten Polewali Mandar.

Penghitungan masing-masing item untuk masing-masing variabel dilakukan dengan cara menentukan terlebih dahulu lebar interval skor, dengan cara menghitung skor tertinggi dan terendah dari butir-butir pernyataan. Masing-masing variabel ini memiliki skor tertinggi tiap pernyataan 5 dan terendah 1 , kemudian dapat diketahui rentang nilai masing-masing item untuk kategori tiap jenjang. Penghitungannya adalah sebagai berikut:

$$
\text { Interval }=\frac{\text { Nilai tertinggi }- \text { Nilai terendah }}{\text { Jumlah kelas }}=\frac{5-1}{5}=0,8
$$

Sehingga dapat ditentukan skala distribusi kriteria pendapat responden sebagai berikut:

1. $1,00-1,80$ : Sangat rendah atau penilaian sangat tidak setuju

2. $1,81-2,60$ : Rendah atau penilaian tidak setuju

3. 2,61 - 3,40 : Sedang atau penilaian ragu-ragu

4. 3,41-4,20 : Tinggi atau penilaian setuju

5. 4,21 - 5,00 : Sangat tinggi atau penilaian sangat setuju

Berdasarkan ketentuan tersebut, maka dapat dilakukan proses pengolahan data untuk menentukan nilai masing-masing pertanyaan atau pernyataan. Adapun hasil selengkapnya adalah sebagai berikut:

\section{Variabel Kompetensi Kerja $\left(\mathbf{X}_{1}\right)$}

Kompetensi kerja adalah suatu kemampuan untuk melaksanakan atau melakukan suatu pekerjaan atau tugas yang dilandasi atas keterampilan dan pengetahuan serta didukung oleh sikap kerja yang dituntut oleh pekerjaan tersebut. Untuk melihat atau mengetahui kompetensi kerja yang dimiliki Aparatur Sipil Negara di Kantor Kecamatan Luyo Kabupaten Polewali Mandar, maka dibutuhkan klasifikasi atau pengkategorian jawaban responden mengenai kompetensi kerja Aparatur Sipil Negara di Kantor Kecamatan Luyo Kabupaten Polewali Mandar sebagaimana disajikan pada tabel 1.

Tabel 1.

Distribusi Frekuensi Jawaban Responden mengenai Kompetensi Kerja Aparatur Sipil Negara Kecamatan Luyo Kabupaten Polewali Mandar

\begin{tabular}{|c|c|c|c|c|}
\hline $\begin{array}{c}\text { Nilai } \\
\text { Jawaban }\end{array}$ & Kategori & $\begin{array}{c}\text { Frekuensi } \\
(\mathbf{F})\end{array}$ & $\begin{array}{c}\text { Persentase } \\
\mathbf{( \% )}\end{array}$ & F x N \\
\hline $4,21-5,00$ & Sangat tinggi & 4 & 22,22 & 20 \\
\hline
\end{tabular}




\begin{tabular}{|c|c|c|c|c|}
\hline $3,41-4,20$ & Tinggi & 9 & 50,00 & 36 \\
\hline $2,61-3,40$ & Sedang & 3 & 16,67 & 9 \\
\hline $1,81-2,60$ & Rendah & 2 & 11,11 & 4 \\
\hline $1,00-1,80$ & Sangat rendah & - & - & 0 \\
\hline Jumlah & & 18 & 100,00 & 69 \\
\hline \multicolumn{4}{|c|}{ Rata-rata } & $\mathbf{3 , 8 3}$ \\
\hline
\end{tabular}

Sumber: Data Primer, diolah 2019

Berdasarkan klasifikasi data pada tabel 1 dapat diketahui bahwa jawaban responden yang berada pada kategori sangat tinggi sebanyak 4 orang (22,22\%), kategori tinggi sebanyak 9 orang (50\%), dan 3 orang $(16,67 \%)$ yang berada pada kategori sedang serta ada 2 orang $(11,11 \%)$ yang berada pada kategori rendah. Nilai rata-rata total item sebesar 3,83 yang masuk dalam kategori penilaian tinggi yang menunjukkan bahwa kompetensi kerja yang dimiliki Aparatur Sipil Negara di Kantor Kecamatan Luyo Kabupaten Polewali Mandar menurut penilaian responden adalah berkategori tinggi.

\section{Variabel Lingkungan Kerja $\left(X_{2}\right)$}

Lingkungan kerja adalah segala sesuatu yang ada di sekitar para pekerja (Aparatur Sipil Negara di Kantor Kecamatan Luyo Kabupaten Polewali Mandar) yang dapat mempengaruhi dirinya dalam menjalankan tugas-tugas yang diembankan. Untuk mengetahui kondisi lingkangan kerja di Kantor Kecamatan Luyo Kabupaten Polewali Mandar, maka dibutuhkan klasifikasi atau pengkategorian jawaban responden mengenai kondisi lingkangan kerja di Kantor Kecamatan Luyo Kabupaten Polewali Mandar sebagaimana disajikan pada tabel 2.

Tabel 2.

Distribusi Frekuensi Jawaban Responden mengenai Lingkangan Kerja di Kantor Kecamatan Luyo Kabupaten Polewali Mandar

\begin{tabular}{|c|c|c|c|c|}
\hline $\begin{array}{c}\text { Nilai } \\
\text { Jawaban }\end{array}$ & Kategori & $\begin{array}{c}\text { Frekuensi } \\
(\mathbf{F})\end{array}$ & $\begin{array}{c}\text { Persentase } \\
(\mathbf{\%})\end{array}$ & F x N \\
\hline $4,21-5,00$ & Sangat Baik & 5 & 27,78 & 25 \\
\hline $3,41-4,20$ & Baik & 10 & 55,56 & 40 \\
\hline $2,61-3,40$ & Sedang & 2 & 11,11 & 6 \\
\hline $1,81-2,60$ & Tidak Baik & 1 & 5,55 & 2 \\
\hline $1,00-1,80$ & Sangat Tidak Baik & 0 & 0,00 & 0 \\
\hline Jumlah & $\mathbf{1 8}$ & $\mathbf{1 0 0 , 0 0}$ & $\mathbf{7 3}$ \\
\hline \multicolumn{4}{|r|}{ Rata-rata } \\
\hline
\end{tabular}

Sumber: Data Primer, diolah 2019

Berdasarkan klasifikasi data pada tabel 2 dapat diketahui bahwa jawaban responden yang berada pada kategori sangat tinggi sebanyak 5 orang $(27,78 \%)$, kategori tinggi sebanyak 10 orang $(55,56 \%)$, dan 2 orang $(11,11 \%)$ yang berada pada kategori sedang serta ada 1 orang $(5,55 \%)$ yang berada pada kategori rendah. Nilai rata-rata total item sebesar 4,06 yang masuk dalam kategori penilaian baik yang menunjukkan bahwa lingkangan kerja yang ada di Kantor Kecamatan Luyo Kabupaten Polewali Mandar menurut penilaian responden adalah sudah terimplementasi dengan baik.

\section{Variabel Peningkatan Kinerja Aparatur Sipil Negara (Y)}

Peningkatan kinerja Aparatur Sipil Negara adalah peningkatan hasil kerja yang dapat dicapai seorang Aparatur Sipil Negara atau sekelompok Aparatur Sipil Negara dalam organisasi Kecamatan 
Luyo sesuai dengan hasil yang diharapkan dalam rangka mencapai tujuan organisasi Kecamatan Luyo dalam periode waktu tertentu berdasarkan standar kerja, target/sasaran yang telah ditentukan terlebih dahulu.

Untuk mengetahui peningkatan kinerja Aparatur Sipil Negara di Kantor Kecamatan Luyo Kabupaten Polewali Mandar, maka dibutuhkan klasifikasi atau pengkategorian jawaban responden mengenai peningkatan kinerja Aparatur Sipil Negara di Kantor Kecamatan Luyo Kabupaten Polewali Mandar sebagaimana disajikan pada tabel 3.

Tabel 3.

Distribusi Frekuensi Jawaban Responden mengenai Peningkatan Kinerja Aparatur Sipil Negara di Kantor Kecamatan Luyo

\begin{tabular}{|c|c|c|c|c|}
\hline $\begin{array}{c}\text { Nilai } \\
\text { Jawaban }\end{array}$ & Kategori & $\begin{array}{l}\text { Frekuensi } \\
\text { (F) }\end{array}$ & $\begin{array}{c}\text { Persentase } \\
(\%)\end{array}$ & $\mathbf{F} \times \mathbf{N}$ \\
\hline $4,21-5,00$ & Sangat Tinggi & 4 & 22,22 & 20 \\
\hline $3,41-4,20$ & Tinggi & 10 & 55,56 & 40 \\
\hline $2,61-3,40$ & Sedang & 2 & 11,11 & 6 \\
\hline $1,81-2,60$ & Rendah & 2 & 11,11 & 4 \\
\hline $1,00-1,80$ & Sangat Rendah & 0 & 0,00 & 0 \\
\hline Jumlah & & 18 & 100,00 & 70 \\
\hline \multicolumn{4}{|c|}{ Rata-rata } & 3,89 \\
\hline
\end{tabular}

Sumber: Data Primer, diolah 2019

Berdasarkan klasifikasi data pada tabel 3 dapat diketahui bahwa jawaban responden yang berada pada kategori sangat tinggi sebanyak 4 orang $(22,22 \%)$, yang berada pada kategori tinggi sebanyak 10 orang $(55,56 \%)$, dan 2 orang $(11,11 \%)$ yang berada pada kategori sedang serta ada 2 orang $(11,11 \%)$ yang berada pada kategori rendah. Nilai rata-rata total item sebesar 3,89 yang masuk dalam kategori penilaian tinggi yang menunjukkan bahwa peningkatan kinerja Aparatur Sipil Negara di Kantor Kecamatan Luyo Kabupaten Polewali Mandar menurut penilaian responden adalah sudah dilakukan dengan baik.

\section{B. Analisis Inferensial Hasil Penelitian dan Pembahasan}

\section{Pengujian Prasyarat}

Asumsi normalitas dan linearitas sangat penting sebelum melakukan pengujian hipotesis tentang pengaruh variabel bebas terhadap variabel terikat. Artinya, uji normalitas data dan uji linearitas merupakan persyaratan analisis regresi dalam analisis inferensial.

Uji normalitas data hasil penelitian yang berupa data dari variabel bebas (kompetensi kerja dan lingkungan kerja) dan data dari variabel terikat (peningkatan kinerja aparatur) dilakukan dengan menggunakan bantuan program SPSS for Windows 21. Hasil analisis pengujian normalitas data menggunakan program SPSS for Windows 21 dengan uji One-Sample Kolmogorov-Smirnov Test pada taraf signifikan $\alpha=0,05$ dapat dilihat pada tabel 4 .

Tabel 4.

One-Sample Kolmogorov-Smirnov Test 


\begin{tabular}{|l|r|r|r|r|r|r|}
\hline \multicolumn{1}{|c|}{ Tests of Normality } \\
& \multicolumn{2}{|c|}{ Kolmogorov-Smirnov $^{a}$} & \multicolumn{3}{|c|}{ Shapiro-Wilk } \\
\cline { 2 - 7 } & Statistic & \multicolumn{1}{|c|}{$d f$} & \multicolumn{1}{c|}{ Sig. } & Statistic & $d f$ & \multicolumn{1}{c|}{ Sig. } \\
\hline Kompetensi Kerja & .134 & 18 & .125 & .962 & 18 & .097 \\
Lingkungan Kerja & .178 & 18 & .117 & .870 & 18 & .082 \\
Peningkatan Kinerja & .077 & 18 & $.200^{*}$ & .974 & 18 & .255 \\
Aparatur & & & & & \\
\hline
\end{tabular}

a. Lilliefors Significance Correction

*. This is a lower bound of the true significance.

Sumber: Data Primer, diolah 2019

Berdasarkan data pada tabel 4 dapat diketahui bahwa nilai signifikansi (Sig.) yang diperoleh dari uji One-Sample Kolmogorov-Smirnov Test untuk uji normalitas data pada masing-masing variabel penelitian adalah sebesar 0,125 untuk variabel kompetensi kerja, sebesar 0,117 untuk variabel lingkungan kerja dan sebesar 0,200 untuk variabel peningkatan kinerja Aparatur Sipil Negara yang masing-masing lebih besar dari nilai $\alpha=0,05$. Dengan demikian, semua data hasil penelitian untuk masing-masing variabel adalah berdistribusi normal.

Untuk mengetahui hubungan linearitas antar variabel yang diteliti (variabel bebas dan variabel terikat), dapat digunakan data hasil uji Coefficients ${ }^{\mathrm{a}}$ seperti ditampilkan pada tabel 5.

Tabel 5.

Hasil Uji Coefficients

\begin{tabular}{|c|c|c|c|c|c|c|}
\hline \multicolumn{7}{|c|}{ Coefficients $\mathrm{s}^{\mathrm{a}}$} \\
\hline & \multirow{2}{*}{ Model } & \multicolumn{2}{|c|}{$\begin{array}{l}\text { Unstandardized } \\
\text { Coefficients }\end{array}$} & $\begin{array}{l}\text { Standardized } \\
\text { Coefficients }\end{array}$ & \multirow{2}{*}{$\mathrm{T}$} & \multirow{2}{*}{ Sig. } \\
\hline & & B & Std. Error & Beta & & \\
\hline \multirow[t]{3}{*}{1} & (Constant) & 46.470 & 7.849 & & 5.720 & .000 \\
\hline & $\begin{array}{l}\text { Kompetensi } \\
\text { Kerja }\end{array}$ & .268 & .138 & .446 & 2.945 & .002 \\
\hline & $\begin{array}{l}\text { Lingkungan } \\
\text { Kerja }\end{array}$ & .298 & .084 & .423 & 3.565 & .001 \\
\hline
\end{tabular}

a. Dependent Variable: Peningkatan Kinerja Aparatur

Sumber: Data Primer, diolah 2019

Berdasarkan tabel 5 dapat diketahui bahwa setiap variabel memiliki hubungan keliniearan antar variabel yang ditandai dengan diperolehnya nilai Sig. linearity masing-masing variabel sebesar 0,00. Nilai Sig. yang dihasilkan jauh lebih kecil dari pada nilai probabilitas $\alpha=0,05(0,00<<0,05)$ yang berarti bahwa antar variabel memiliki hubungan yang linear. Dengan terpenuhinya asumsi normalitas dan linearitas maka pengujian hipotesis penelitian menggunakan analisis regresi linear berganda dapat dilanjutkan.

\section{Pengujian Hipotesis Penelitian}

Hipotesis penelitian ini seperti yang telah dikemukakan pada bab sebelumnya, perlu diuji untuk mengetahui apakah hipotesis penelitian ini dapat diterima atau ditolak sebagai dasar untuk 
menarik kesimpulan. Ketiga hipotesis penelitian yang telah dikemukakan sebelumnya, masingmasing dapat dijabarkan sebagai berikut:

a. Pengaruh Kompetensi Kerja terhadap Peningkatan Kinerja Aparatur

Data-data hasil analisis correlation dapat digunakan untuk menguji signifikansi hubungan variabel kompetensi kerja $\left(\mathrm{X}_{1}\right)$ dan peningkatan kinerja Aparatur Sipil Negara (Y). Hasil correlation diperlihatkan pada tabel 6 .

Tabel 6.

Nilai Correlation Hasil Analisis Regresi Linear Ganda

\begin{tabular}{|ll|r|r|r|}
\hline \multicolumn{4}{|c|}{ Correlations } \\
\hline Kompetensi & $\begin{array}{c}\text { Kompetensi } \\
\text { Kerja }\end{array}$ & $\begin{array}{c}\text { Lingkungan } \\
\text { Kerja }\end{array}$ & $\begin{array}{c}\text { Peningkatan } \\
\text { Kinerja Aparatur }\end{array}$ \\
\cline { 3 - 4 } & Sig. (2-tailed) & 1 & -.051 & .454 \\
& $\mathrm{~N}$ & 18 & .712 & .002 \\
Lerja & Pearson Correlation & -.051 & 18 & 18 \\
Kingkungan & Sig. (2-tailed) & .712 & 18 & $.427^{* *}$ \\
& $\mathrm{~N}$ & 18 & 18 & .001 \\
Kerja & Pearson Correlation & .454 & $.427^{* *}$ & 18 \\
Keningkatan & Sig. (2-tailed) & .002 & .001 & 1 \\
Aparatur & $\mathrm{N}$ & 18 & 18 & 18 \\
\hline
\end{tabular}

**. Correlation is significant at the 0.01 level (2-tailed).

Sumber: Data Primer, diolah 2019

Bardasarkan tabel 6 dapat diketahui bahwa nilai correlation kompetensi kerja $\left(\mathrm{X}_{1}\right)$ dan peningkatan kinerja Aparatur Sipil Negara (Y) yang diperoleh adalah sebesar 0,454 yang menunjukkan tingkat hubungan yang cukup kuat antara variabel kompetensi kerja $\left(\mathrm{X}_{1}\right)$ dan peningkatan kinerja Aparatur Sipil Negara (Y). Untuk menguji signifikansi hubungan variabel $\mathrm{X}_{1}$ dan Y, maka hipotesis penelitian dirumuskan secara statistik sebagai berikut:

$$
\text { Ho }: r_{Y X 1} \neq 0 \quad \text { dan } \quad \text { Ha }: r_{Y X 1}=0
$$

dan hipotesis dalam bentuk kalimat adalah:

Ho : Kompetensi kerja berhubungan secara tidak signifikan dengan peningkatan kinerja Aparatur Sipil Negara.

Ha : Kompetensi kerja berhubungan secara signifikan dengan peningkatan kinerja Aparatur Sipil Negara.

Dengan kaidah keputusan atau ketentuan:

1) Jika nilai 0,05 lebih kecil dari pada nilai probabilitas Sig. $(0,05<\mathrm{Sig})$, maka Ho diterima dan Ha ditolak, artinya tidak signifikan.

2) Jika nilai 0,05 lebih besar atau sama dengan nilai probabilitas Sig. (0,05 $\geq$ Sig), maka Ho ditolak dan Ha diterima, artinya signifikan.

Bardasarkan pada tabel 6 tentang nilai correlation, diperoleh nilai Sig. (2-tailed) dari variabel kompetensi kerja $\left(\mathrm{X}_{1}\right)$ dan peningkatan kinerja Aparatur Sipil Negara $(\mathrm{Y})$ sebesar 0,002 yang lebih 
kecil dari pada nilai probabilitas $0,05(0,05>0,002)$ yang berarti Ho ditolak dan Ha diterima. Dengan demikian, kompetensi kerja berhubungan secara signifikan dengan peningkatan kinerja Aparatur Sipil Negara di Kantor Kecamatan Luyo Kabupaten Polewali Mandar.

Untuk menentukan bahwa model regresi ganda dapat dipakai dalam memprediksi peningkatan kinerja Aparatur Sipil Negara di Kantor Kecamatan Luyo Kabupaten Polewali Mandar, maka nilai dari hasil uji ANOVA dapat digunakan. Hasil uji ANOVA ditampilkan pada tabel 7.

Tabel 7.

Hasil Uji ANOVA

\begin{tabular}{|ll|r|r|r|r|r|}
\hline \multicolumn{7}{|c|}{ ANOVA $^{\mathbf{b}}$} \\
\hline \multirow{2}{*}{ Model } & $\begin{array}{c}\text { Sum of } \\
\text { Squares }\end{array}$ & $d f$ & Mean Square & $F$ & \multicolumn{1}{c|}{ Sig. } \\
\hline $1 \quad$ Regression & 497.123 & 2 & 248.562 & 7.892 & $.001^{\mathrm{a}}$ \\
& Residual & 1633.713 & 15 & 31.418 & & \\
Total & 2130.836 & 17 & & & \\
\hline
\end{tabular}

a. Predictors: (Constant), Kompetensi Kerja, Lingkungan Kerja

b. Dependent Variable: Peningkatan Kinerja Aparatur

Sumber: Data Primer, diolah 2019

Bardasarkan tabel 7 tentang hasil uji ANOVA diperoleh keterangan bahwa nilai $\mathrm{F}$ yang dihasilkan sebesar 7,892 dengan tingkat probabilitas Sig. $=0,001$ yang lebih kecil dari probabilitas $0,05(0,001<0,05)$. Dengan demikian, model regresi ganda dapat dipakai untuk memprediksi peningkatan kinerja Aparatur Sipil Negara di Kantor Kecamatan Luyo Kabupaten Polewali Mandar berdasarkan kompetensi kerja yang dimilikinya.

Selanjutnya untuk menentukan persamaan dari $\hat{Y}=a+b_{1} X_{1}$ digunakan hasil uji coefficients (tabel 5). Bardasarkan data pada hasil uji coefficients (tabel 5) dapat diketahui bahwa pada variabel kompetensi kerja diperoleh nilai konstanta $(a)=46,470$ dan beta $\left(\beta_{1}\right)=0,446$ serta nilai $t_{\text {hitung }}=2.945$ dan tingkat Sig. $=0,002$. Dengan demikian, diperoleh persamaan regresinya sebagai berikut:

$$
\hat{\mathrm{Y}}=46,470+0,446 \mathrm{X}_{1}
$$

Untuk menguji koefisien regresi dan variabel kompetensi kerja dengan menggunakan uji-t, maka hipotesis statistiknya dirumuskan sebagai berikut:

Ho $: \mathrm{P}_{\mathrm{yx} 1}=0$ dan $\mathrm{Ha}: \mathrm{P}_{\mathrm{yx} 1} \neq 0$

dan hipotesis dalam bentuk kalimat adalah:

Ho : Kompetensi kerja tidak berpengaruh signifikan terhadap peningkatan kinerja Aparatur Sipil Negara di Kantor Kecamatan Luyo.

$\mathrm{Ha}$ : Kompetensi kerja berpengaruh signifikan terhadap peningkatan kinerja Aparatur Sipil Negara di Kantor Kecamatan Luyo.

Dengan kaidah keputusan atau ketentuan:

1) Jika nilai $t_{\text {hitung }}>t_{\text {tabel, }}$, maka Ho ditolak dan Ha diterima, artinya ada pengaruh yang signifikan.

2) Jika nilai $t_{\text {hitung }} \leq t_{\text {tabel, }}$, maka Ho diterima dan Ha ditolak, artinya tidak ada pengaruh yang signifikan. 
Berdasarkan tabel 5 tentang hasil uji coefficients diketahui bahwa nilai $t_{\text {hitung }}=2.945$, sedangkan nilai tabel untuk $\alpha=0,05 \mathrm{dan} \mathrm{dk}=18-2=16$ adalah sebesar 1,99 sehingga diperoleh bahwa nilai $t_{\text {hitung }}>t_{\text {tabel }}$ atau $2.945>1$,99 yang berarti bahwa Ho ditolak dan Ha diterima. Dengan demikian, kompetensi kerja berpengaruh positif dan signifikan terhadap peningkatan kinerja Aparatur Sipil Negara di Kantor Kecamatan Luyo Kabupaten Polewali Mandar.

Berdasarkan persamaan regresi $\left(\hat{\mathrm{Y}}=46,470+0,446 \mathrm{X}_{1}\right)$ yang diperoleh dari hasil uji coefficients, maka tingkat pengaruh kompetensi kerja terhadap peningkatan kinerja Aparatur Sipil Negara di Kantor Kecamatan Luyo Kabupaten Polewali Mandar dapat dihitung sebagai berikut:

Tingkat pengaruh $=(0,446)^{2} \times 100 \%=0,1989 \times 100 \%=19,89 \%$

Jadi, secara parsial dan langsung, tingkat pengaruh kompetensi kerja terhadap peningkatan kinerja Aparatur Sipil Negara di Kantor Kecamatan Luyo Kabupaten Polewali Mandar adalah sebesar $19,89 \%$.

b. Pengaruh Lingkungan Kerja terhadap Peningkatan Kinerja Aparatur

Bardasarkan tabel 6 tentang nilai correlation dapat diketahui bahwa nilai correlation lingkungan kerja $\left(\mathrm{X}_{2}\right)$ dan peningkatan kinerja Aparatur Sipil Negara (Y) yang diperoleh adalah sebesar 0,427 yang menunjukkan tingkat hubungan yang cukup kuat antara variabel lingkungan kerja $\left(\mathrm{X}_{2}\right)$ dan peningkatan kinerja Aparatur Sipil Negara (Y). Untuk menguji signifikansi hubungan variabel $\mathrm{X}_{2}$ dan $\mathrm{Y}$, maka hipotesis penelitian dirumuskan secara statistik berikut:

Ho : $r_{Y X 2} \neq 0$ dan Ha : $r_{Y X 2}=0$

Hipotesis dalam bentuk kalimat adalah:

Ho : Lingkungan kerja tidak berhubungan secara signifikan dengan peningkatan kinerja Aparatur Sipil Negara di Kantor Kecamatan Luyo.

$\mathrm{Ha}$ : Lingkungan kerja berhubungan secara signifikan dengan peningkatan kinerja Aparatur Sipil Negara di Kantor Kecamatan Luyo.

Dengan kaidah keputusan atau ketentuan:

1) Jika nilai 0,05 lebih kecil dari pada nilai probabilitas Sig. $(0,05<\mathrm{Sig})$, maka Ho diterima dan Ha ditolak, artinya tidak signifikan.

2) Jika nilai 0,05 lebih besar atau sama dengan nilai probabilitas Sig. (0,05 $\geq \mathrm{Sig})$, maka Ho ditolak dan Ha diterima, artinya signifikan.

Bardasarkan pada tabel 6 tentang nilai correlation, diperoleh nilai Sig. (2-tailed) dari variabel lingkungan kerja $\left(\mathrm{X}_{2}\right)$ dan peningkatan kinerja Aparatur Sipil Negara (Y) sebesar 0,001. Nilai Sig. (2-tailed) lebih kecil dari pada nilai probabilitas 0,05 atau 0,05 $>0,001$ yang berarti Ho ditolak dan Ha diterima. Dengan demikian, lingkungan kerja berhubungan secara signifikan dengan peningkatan kinerja Aparatur Sipil Negara di Kantor Kecamatan Luyo Kabupaten Polewali Mandar.

Bardasarkan tabel 7 tentang hasil uji ANOVA diperoleh keterangan bahwa nilai $\mathrm{F}$ yang dihasilkan sebesar 7.892 dengan tingkat probabilitas Sig. $=0,001$ yang lebih kecil dari probabilitas $0,05(0,001<0,05)$. Dengan demikian, model regresi ganda dapat dipakai untuk memprediksi peningkatan kinerja Aparatur Sipil Negara di Kantor Kecamatan Luyo berdasarkan lingkungan kerja di Kantor Kecamatan Luyo Kabupaten Polewali Mandar. 
Bardasarkan data pada tabel 5 tentang hasil uji coefficients dapat diketahui bahwa pada variabel lingkungan kerja diperoleh nilai konstanta (a) sebesar 46,470 dan beta $\left(\beta_{2}\right)$ sebesar 0,423 serta nilai $\mathrm{t}_{\text {hitung }}$ sebesar 3.565 dan tingkat Sig. $=0,001$ sehingga diperoleh persamaan regresinya:

$$
\hat{\mathrm{Y}}=46,470+0,423 \mathrm{X}_{2}
$$

Untuk menguji koefisien regresi dan variabel lingkungan kerja dengan menggunakan uji-t, maka hipotesis statistiknya dirumuskan sebagai berikut:

$$
\begin{array}{ll}
\text { Ho : } & \mathrm{P}_{\mathrm{yx} 2}=0 \\
\mathrm{Ha}: & \mathrm{P}_{\mathrm{yx} 2} \neq 0
\end{array}
$$

dan hipotesis dalam bentuk kalimat adalah:

Ho : Lingkungan kerja tidak berpengaruh signifikan terhadap peningkatan kinerja Aparatur Sipil Negara di Kantor Kecamatan Luyo.

$\mathrm{Ha}$ : Lingkungan kerja berpengaruh signifikan terhadap peningkatan kinerja Aparatur Sipil Negara di Kantor Kecamatan Luyo.

Dengan kaidah keputusan atau ketentuan:

1) Jika nilai $t_{\text {hitung }}>t_{\text {tabel, }}$, maka Ho ditolak dan Ha diterima, artinya ada pengaruh yang signifikan.

2) Jika nilai $t_{\text {hitung }} \leq t_{\text {tabel, }}$ maka Ho diterima dan Ha ditolak, artinya tidak ada pengaruh yang signifikan.

Berdasarkan tabel 5 tentang hasil uji coefficients diketahui bahwa nilai thitung $=3.565$ dan nilai $\mathrm{t}_{\text {tabel }}$ untuk $\alpha=0,05 \mathrm{dan} \mathrm{dk}=18-2=16$ adalah sebesar 1,99 sehingga diperoleh bahwa nilai $\mathrm{t}_{\text {hitung }}>$ $t_{\text {tabel }}$ atau 3.565 $>1,99$ yang berarti bahwa Ho ditolak dan Ha diterima. Dengan demikian, lingkungan kerja berpengaruh positif dan signifikan terhadap peningkatan kinerja Aparatur Sipil Negara di Kantor Kecamatan Luyo Kabupaten Polewali Mandar.

Berdasarkan persamaan regresi $\left(\hat{\mathrm{Y}}=46,470+0,423 \mathrm{X}_{2}\right)$ yang diperoleh dari hasil uji coefficients, maka tingkat pengaruh lingkungan kerja terhadap peningkatan kinerja Aparatur Sipil Negara di Kantor Kecamatan Luyo Kabupaten Polewali Mandar dapat dihitung berikut:

$$
\text { Tingkat pengaruh }=(0,423)^{2} \times 100 \%=0,1789 \times 100 \%=17,89 \%
$$

Jadi secara parsial dan langsung, tingkat pengaruh lingkungan kerja terhadap peningkatan kinerja Aparatur Sipil Negara di Kantor Kecamatan Luyo Kabupaten Polewali Mandar adalah sebesar $17,89 \%$.

c. Pengaruh Kompetensi Kerja dan Lingkungan Kerja terhadap Peningkatan Kinerja Aparatur Sipil Negara

Uji secara keseluruhan, yaitu koefisien regresi untuk variabel kompetensi kerja dan variabel lingkungan kerja didasarkan pada tabel 7 tentang hasil uji ANOVA dan tabel 5 tentang hasil uji coefficients yang diperoleh dari hasil analisis regresi linear ganda.

Bardasarkan data pada tabel 7 tentang hasil uji ANOVA diperoleh keterangan bahwa nilai $\mathrm{F}$ yang dihasilkan sebesar 7.892 dengan tingkat probabilitas Sig. $=0,001$ yang lebih kecil dari probabilitas $0,05(0,001<0,05)$. Dengan demikian, model regresi ganda dapat dipakai untuk memprediksi peningkatan kinerja aparatur berdasarkan kompetensi kerja dan lingkungan kerja.

Bardasarkan data pada tabel 5 tentang hasil uji coefficients dapat diketahui bahwa pada variabel kompetensi kerja $\left(\mathrm{X}_{1}\right)$ diperoleh nilai koefisien $\beta_{1}=0,446$ dan pada variabel lingkungan kerja $\left(\mathrm{X}_{2}\right)$ diperoleh nilai koefisien $\beta_{2}=0,423$ dengan nilai $\mathrm{B}$ atau konstanta (a) sebesar 46,470 sehingga 
diperoleh kerangka hubungan kausal empiris antara $\mathrm{X}_{1}$ dan $\mathrm{X}_{2}$ terhadap $\mathrm{Y}$ dengan persamaan strukturalnya sebagai berikut:

$$
\begin{aligned}
& Y=a+\rho_{\mathrm{yx} 1} X_{1}+\rho_{\mathrm{yx} 2} X_{2}=\mathrm{a}+\beta_{1} X_{1}+\beta_{2} X_{2} \\
& Y=46,470+0,446 X_{1}+0,423 X_{2}
\end{aligned}
$$

Untuk menguji koefisien regresi, variabel kompetensi kerja $\left(\mathrm{X}_{1}\right)$ dan variabel lingkungan kerja $\left(\mathrm{X}_{2}\right)$ dengan menggunakan nilai probabilitas yang diperoleh dari hasil uji coefficients, maka hipotesis statistiknya dirumuskan sebagai berikut:

$$
\begin{aligned}
& \text { Ho }: \rho_{\mathrm{yx} 1}=\rho_{\mathrm{yx} 2}=0 \\
& \text { Ha }: \rho_{\mathrm{yx} 1}=\rho_{\mathrm{yx} 2} \neq 0
\end{aligned}
$$

dan hipotesis dalam bentuk kalimat adalah:

Ho : Kompetensi kerja dan lingkungan kerja tidak berpengaruh secara simultan dan signifikan terhadap peningkatan kinerja Aparatur Sipil Negara di Kantor Kecamatan Luyo.

Ha : Kompetensi kerja dan lingkungan kerja berpengaruh secara simultan dan signifikan terhadap peningkatan kinerja Aparatur Sipil Negara di Kantor Kecamatan Luyo.

Dengan kaidah keputusan atau ketentuan:

1) Jika nilai 0,05 lebih kecil atau sama dengan nilai Sig. $(0,05 \leq$ Sig. $)$, maka Ho diterima dan Ha ditolak, artinya tidak signifikan.

2) Jika nilai 0,05 lebih besar dari pada nilai Sig. (0,05 > Sig.), maka Ho ditolak dan Ha diterima, artinya signifikan.

Bardasarkan data pada tabel 7 tentang hasil uji ANOVA diperoleh keterangan bahwa nilai $\mathrm{F}$ yang dihasilkan sebesar 7.892 dengan tingkat probabilitas Sig. $=0,001$ yang lebih kecil dari probabilitas $0,05(0,001<0,05)$ yang berarti Ho ditolak dan Ha diterima. Dengan demikian, kompetensi kerja dan lingkungan kerja berpengaruh secara simultan dan signifikan terhadap peningkatan kinerja Aparatur Sipil Negara di Kantor Kecamatan Luyo Kabupaten Polewali Mandar.

Tingkat pengaruh kompetensi kerja dan lingkungan kerja secara simultan dan langsung terhadap peningkatan kinerja Aparatur Sipil Negara di Kantor Kecamatan Luyo Kabupaten Polewali Mandar dapat ditentukan berdasarkan pada Tabel Model Summary yang dihasilkan dari analisis regresi linear ganda seperti diperlihatkan pada tabel 8 .

Berdasarkan data pada tabel 8 dapat diketahui bahwa nilai koefisien determinasi atau nilai $R$ square $\left(\mathrm{R}^{2}\right)$ yang dihasilkan adalah sebesar 0,252 sehingga tingkat pengaruh kompetensi kerja dan lingkungan kerja secara simultan dan langsung terhadap peningkatan kinerja Aparatur Sipil Negara di Kantor Kecamatan Luyo Kabupaten Polewali Mandar dapat dihitung sebagai berikut:

$$
\text { Tingkat pengaruh }=\mathrm{R}^{2} \times 100 \%=0,252 \times 100 \%=25,2 \%
$$

Tabel 8.

Model Summary ${ }^{\mathrm{b}}$ 


\begin{tabular}{|r|r|r|r|r|}
\hline \multicolumn{6}{|c|}{ Model Summary $^{\mathbf{b}}$} \\
\hline Model & \multicolumn{1}{|c|}{$\mathrm{R}$} & \multicolumn{1}{|c|}{$\mathrm{R}$ Square } & Adjusted R Square & $\begin{array}{c}\text { Std. Error of the } \\
\text { Estimate }\end{array}$ \\
\hline 1 & $.502^{\mathrm{a}}$ & .252 & .214 & 5.712 \\
\hline
\end{tabular}

a. Predictors: (Constant), Kompetensi Kerja, Lingkungan Kerja

b. Dependent Variable: Peningkatan Kinerja Aparatur

Sumber: Data Primer, diolah 2019

Jadi secara simultan dan langsung, tingkat pengaruh kompetensi kerja dan lingkungan kerja terhadap peningkatan kinerja Aparatur Sipil Negara di Kantor Kecamatan Luyo Kabupaten Polewali Mandar adalah sebesar 25,2\%. Sedangkan sisanya sebesar 74,8\% dipengaruhi faktor-faktor lain yang tidak dapat dijelaskan dalam penelitian ini.

\section{PENUTUP}

\section{A. Simpulan}

Berdasarkan hasil penelitian sebagaimana telah dijelaskan sebelumnya, maka simpulan yang dapat diambil adalah:

1. Kompetensi kerja berpengaruh positif dan signifikan terhadap peningkatan kinerja Aparatur Sipil Negara di Kantor Kecamatan Luyo Kabupaten Polewali Mandar dengan tingkat pengaruh sebesar $19,89 \%$.

2. Lingkungan kerja berpengaruh positif dan signifikan terhadap peningkatan kinerja Aparatur Sipil Negara di Kantor Kecamatan Luyo Kabupaten Polewali Mandar dengan tingkat pengaruh sebesar $17,89 \%$.

3. Secara simultan dan langsung, kompetensi kerja dan lingkungan kerja berpengaruh positif dan signifikan terhadap peningkatan kinerja Aparatur Sipil Negara di Kantor Kecamatan Luyo Kabupaten Polewali Mandar dengan tingkat pengaruh sebesar 25,2\%. Sedangkan sisanya sebesar $74,8 \%$ dipengaruhi faktor-faktor lain yang tidak dapat dijelaskan dalam penelitian ini.

\section{B. Saran}

Berdasarkan kesimpulan di atas, maka disarankan agar Camat dan Aparatur Sipil Negara di Kantor Kecamatan Luyo Kabupaten Polewali Mandar lebih meningkatkan perhatiannya terhadap peningkatan kompetensi kerja aparatur, khususnya pada aspek kesesuaian latar belakang pendidikan dengan bidang pekerjaan aparatur dan pada aspek kemampuan aparatur dalam membuat rencana kerja. Juga dalam peningkatan kondisi lingkungan kerja, khususnya pada aspek kebutuhan ruang gerak yang luas dalam bekerja sehingga kinerja aparatur dapat lebih optimal karena kompetensi kerja aparatur maupun kondisi lingkungan kerja berpengaruh positif terhadap peningkatan kinerja aparatur.

\section{DAFTAR PUSTAKA}

Arikunto, Suharsimi. Prosedur Penelitian Suatu Pendekatan Praktik. Jakarta: Rineka Cipta, 2013. Boediono, B. Pelayanan Prima Perpajakan. Jakarta: Rineka Cipta, 2013.

Dharma, Agus. Manajemen Personalia Teknik dan Konsep Modern. Jakarta: Erlangga, 2014. 
Girsang. Manajemen Sumber Daya Manusia dan Organisasi. Yogyakarta: Graha Ilmu, 2011.

Ghozali, Imam. Aplikasi Analisis Multivariate dengan Program SPSS. Semarang: B-P UNDIP, 2013.

Hayat, Yusuf. Pengaruh Kualitas Layanan Terhadap Kepuasan Konsumen, Citra Perusahaan, dan Loyalitas Konsumen Pada Perusahaan Jasa (Studi Pada Jasa Penerbangan di Sulawesi Selatan. Tesis. Malang: Program Pascasarjana Unibraw, 2014.

Mangkunegara, Anwar P. Manajemen Sumber Daya Manusia Perusahaan. Cetakan Ke-8. Bandung: Rosdakarya, 2009.

Moeheriono. Pengembangan Sumber Daya Manusia. Jakarta: Gramedia, 2013.

Ratminto dan Atik Septiwinarsih. Manajemen Pelayanan. Yogyakarta: Pustaka Pelajar, 2012.

Republik Indonesia, Undang-Undang Republik Indonesia No. 13 Tahun 2003 Tentang Ketenagakerjaan.

Robbins, Stephen P. Prinsip-Prinsip Perilaku Organisasi. Jakarta: Erlangga, 2011.

Sarworini. Produktivitas Kerja Dalam Organisasi. Yogyakarta: Graha Ilmu, 2013.

Sedarmayanti. Tata Kerja dan Produktivitas Kerja. Bandung: Mandar Maju, 2011.

Siregar, Syofian P. Statistik Deskriptif Untuk Penelitian. Jakarta: Raja Grafindo Persada, 2010.

Sugiyono. Metode Penelitian Pendekatan Kuantitatif, Kualitatif, dan R \& D. Bandung: Alfabeta, 2015.

Sumarsono. Evaluasi Kinerja Organisasi. Jakarta: Bumi Aksara. 2012.

Thoha, Miftah. Manajemen Kepegawaian Sipil di Indonesia. Jakarta: Kencana Prenada, 2014.

Wahyuni. Pelayanan Publik di Era Globalisasi. Semarang: Unnes Press, 2014.

Wijaya dan Suhaji. Produktivitas dan Kinerja Organisasi. Jakarta: Bumi Aksara, 2013.

Yusri. Statistika Sosial: Aplikasi dan Interpretasi. Yogyakarta: Graha Ilmu, 2009. 